熱帯林のエコロジカルサービスを探る 一生態研究の接点と統合環境管理プロジェクトへ向けてー

\title{
Studies on Ecological Services of Tropical Forest - Laying the groundwork for ecological studies and integrated ecosystem management-
}

\author{
奥田 敏統 \\ 吉田圭一郎 \\ 足立 直樹 \\ Toshinori OKUDA \\ Keiichiro YosHIDA \\ Naoki ADACHI \\ 国立環境研究所＝305-8506 茨城県つくば市小野川16-2 \\ 同上 \\ マレーシア森林研究所 52109 マレーシア, タアラルンプール, ケポン \\ National Institute for Environmental Studies, 16-2 Onogawa, Tsukuba 305-8506 Japan \\ ditto \\ Forest Research Institute Malaysia, Kepong, Kuala Lumpur, 52109 Malaysia
}

\begin{abstract}
The development of integrated ecosystem management of tropical forests requires studies of the ecological service values and goods of these forests. Studies should begin with a review of the functional aspects of the various types of ecosystems in the target study area. New data should then be collected to create a database of ecological service values and goods. This database can be used for analyses of the inter-linkage between the different types of ecological services. Studies of highly diverse biomes such those in tropics need tools that can optimize the values of the different types of ecological services, particularly conflicting ecological services, such as biodiversity and timber production or carbon sequestration. The database will allow the development of a risk assessment program, a landscape zoning plan, and other planning instruments that play important roles in integrated ecosystem management.
\end{abstract}

Key words: database / ecological services and goods / economical assessment / GIS / integrated ecosystem management/landscape zoning / risk assessment データベース/エコロジカルサービスと財/経済的アセスメント/GIS/統合環境管理/ランドスケー プゾーニング/リスクアセスメント

エコロジカルサービス（Ecological Services）とは，人間社会が直接的，間接的に生態系の諸機能から 受ける利益・恩恵をさす。我が国では古くからこれに相当する言葉として「公益機能」が用いられて きたが, エコロジカルサービスが生態系の諸機能から享受できるサービスの定量的評価, すなわち経 済的な指標などによる「評価の基準化」を念頭に置いているのに対し，「公益機能」は一般に生態系 諸機能の概念化とカテゴリー化を目指して用いられてきた。エコロジカルサービスと類似する用語と して「エコシステムサービス（Ecosystem Services）」(Costanza et al., 1997, Daily et al., 1997) があるが, エコシステムサービスは特定の生態系を対象とするのに対して, エコロジカルサービスはやや包括的 なニュアンスをもって使われる。

表 1 には, 大まかに整理したエコロジカルサービスの機能を列挙した。これら以外の機能にも, 例 えば廃棄物処理機能や生物相の制御機能などをを加える場合もある (Daily et al., 1997)。また, エコロ ジカルサービスの経済評価を行う場合にはダブルカウンティングによる過大評価を防ぐため, それぞ 
表 1. 主な森林のエコロジカルサービス

物質生产機能（木材生産，その他林産物生産）

気象緩和機能 (気温・地温緩和, 湿潤調節)

大気調節 (炭素蓄積, 酸素供給, 塵埃吸着)

水源涵養機能（水の貯留，水質浄化）

浸食防止·自然災害軽隇機能 (水食·風食防止, 山崩れ, 水害防止)

土壤保全機能 (土壤形成, 栄養塩類循環調節)

生物多様性保全機能（野生生物，遺伝子資源保全）

保健文化機能（リクレーション，自然学習，芸術，景観保全，快適な生活環境の提供）

れの研究例で独自の類型を行っている（例えば，Adger et al., 1995; Kumari, 1996）。表1では物質生産機 能として示したが，木材などの生態系から得られる生産物などの財そのものはサービス機能とは区別 し，エコロジカルサービスと併せて“services and goods”という表現をする場合も多い。同様に公益 機能にも，例えば，商業伐採などによる木材供給機能などは含まないとする見解がある（山縣ほか， 1989）。これらはエコロジカルサービスや公益機能が特定のグループや社会が受ける利益を除外した， 広く一般の人々や社会が被るサービス機能であると考えられるためであろう。このように，エコロジ カルサービスや公益機能の概念や区分については研究者や資源管理者などによって若干のずれが生じ ており，かなり曖昧な使われ方がされてきた。また，これらは時代背景や社会状況などによって変化 しうるものと考えられる。

近年，エコロジカルサービスが盛んに取り上げられるようになったが，その背景には，地球的規模 の森林破壊, 砂漠化, 水域の污染などが関係する。水や空気は夕ダと思って使いたいだけ使い, 污せ るだけ污したーところが，こうした自然資源には様々なサービス機能があり，それらを無視あるいは 軽視し続けた人間社会への反動となり多くの被害が生じてきた。例えば，地球の温暖化，各地で深刻 化する酸性雨，異常気象に伴う大規模な風水害など，枚挙にいとまがない。これらは，そもそも生態 系が保持するサービス機能がどのくらいの価值をもっているかが正しく理解されず，過小評価されて きたことに起因する。したがって，生態系から得られるサービスは夕ダではないのだという主張を行 う必要性が生じたのである。また熱帯域の生態系に関していえば，森林破壊や劣化の速度は一向に止 まるところをみせず，地域社会や地球環境にも深刻な影響を及ぽすようになってきた。熱帯林減少の 背景にはそれぞれの地域がもつ貧困や政治・経済システムなどに起因する様々な社会問題が深く関わ っており，その複雑性から単に生態学的な研究アプローチだけで，もやは解決の糸口を見いだすこと がなかなか難しい状況であるのが現状である。こうしたことから，熱帯生態系におけるエコロジカル サービスおよびその評価に関する研究が近年注目を集めるようになってきた。

このような背景から, 我々は2001年6月に東京都立大学での第11回日本熱帯生態学会年次大会にお いて「熱帯林のエコロジカルサービスを探る」というタイトルで公開シンポジウムを開催した。本シ ンポジウムでは, 熱帯林生態系のエコロジカルサービスの機能について, 森林の炭素蓄積・吸収機能 の視点から小泉・安立・別宮氏 (岐阜大学, 都留文科大学) に, 集水域の保全機能の立場から森林の もつ自然のダムとしての機能について野口氏（森林総合研究所）に, 多様性の保全機能の視点から遺 伝子の宝庫としての熱带林の価値について津村氏（森林総合研究所）に，地域住民にとっての森林の 価値について栗山氏 (早稲田大学) に, 二酸化炭素吸収源としての熱帯林の経济評価について森田氏 （国立環境研究所）に講演をお願いし，今回の特集号掲載論文としてそれぞれまとめていただいた。 本稿はシンポジウムの中で「エコロジカルサービスとは」と題して奥田・吉田（国立環境研究所）が 
行った講演内容および，これまでのエコロジカルサービスに関する研究の経緯や背景，及び今後の研 究の展開について述べたものである。

\section{エコロジカルサービスの経済評価}

エコロジカルサービスはどのように評価されるのだろうか。エコロジカルサービスを評価する方法と してこれまでにも例えばアメニティー度などの間接的な評価手法があったが, 直接的に日常生活の中 で用いる尺度としては非常にわかりにくいため，とりあえず経済的尺度に置き換えて評価を試みる一 これがエコロジカルサービスの経済評価である。確かに生態系の機能そのものには未だ多くの不明な 点があるため, 一足飛びに経済評価を行うというアプローチやその効果に対して, 例えば以下のよう な批判的な意見がある。

1）森林の社会的価值および経済的価值は社会のもつ余剩経済力によって絶えず変化するため, 一時的な経済価値基準に置き換えた評価はあまり意味を持たない。

2）現在深刻化している熱帯林の減少を例にとると，その背景には貧困，盗伐，焼き畑などがあ り，実体のない経済評価は問題の解決にあまりにも無力である。

3）経済評価によって出てきた数字が一人歩きをしてしまう可能性が高く, 逆にその代価を支払 えば，開発を行ってもよいという免罪符を与えてしまう。

しかしながら，ここで指摘せねばならないことは，そもそも経済評価は森林などの生態系が保持する サービス機能に対して絶対的な価值基準を設定しょうとしているのではないという点である。すなわ ち経済評価によって生態系の「元手」に值段をつけるのではなく，対象とする生態系が人為的攪乱な どにより改変されたときに生ずる経済的損失を評価しようとしているのである (Costanza et al., 1997)。

また，たとえ上述したような誤解が解けたとしても，森の生き物などから得られる恩恵など有形無 形の価值に対しては本来は值札は付けれないという拒絶反応は簡単に払拭できるものではなく, 経済 評価はモラルに反するといった批判が出てくるのも当然である。しかしながら，近年の自然生態系の 破壊の規模はあまりにも大きく，熱帯域を中心に急速に広がる無秩序な開発や反モラル的な行為に対 して，残念ながらモラル的な理屈で，明確かつ，迅速に対応できる明快な答えが十分に準備されてい るとは言い難い状況である（Costanza et al., 1997)。一部で環境倫理からのアプローチも始まりつつあ るが，熱帯林減少に対処するためには，今後の研究に多くの人的，時間的投資を行う必要があるもの と思われる。順序からいえば，まず生態系の機能を解き明かし，その意義やサービス機能を生態学的 な視点から客観的に評価するべきであるが，一刻の猶予も許されない自然資源劣化の現状を鑑みれば 何らかの警鐘が必要であり，そこで環境経済学的アプローチが登場したと見ることも出来る。

エコロジカルサービスの経済評価から得られるアウトプットは地域やグローバルスケールでの社会 経済活動の様々な指標とリンクして解析することが可能である。したがって，これまで生態系の様々 な事象は, 人間活動とは独立したものとして評価, 認識されがちであったが, エコロジカルサービス の経済評価を用いることにより政策決定や地域住民との合意形成に至るまでの一連の流れが形成でき るという点において意義がある。一方で，エコロジカルサービスの経済評価によって得られる価值は 絶えず時間的，社会経済的背景によって変化するため，政策決定や合意形成を行うためにはどのよう な条件設定でその評価に至ったかという点が第三者にわかりやすく示される必要がある。例えば，自 然環境の改変を伴う開発計画にゴーサインを出すか，あるいはストップさせるか，またどの程度のリ スクがありそれに対する補償をどうすべきか，という問いに対して一定の基準に基づいた根拠を示せ 
表 2.グローバルスケールで見た全エコロジカルサービスの経済的価值

(Costanza et al., 1997 より抜粋)

\begin{tabular}{lc}
\hline エコロジカルサービス & 価値 (兆US $\$$ ) \\
機能別 & \\
大気成分調節 & 1.3 \\
攪乱調節（風水害など） & 1.8 \\
廃棄物処理（污染物質浄化など） & 2.3 \\
塩類循環（炭素, 窒素循環など） & 17.0 \\
その他 & 10.6 \\
生態系別 & \\
海洋 & 21.0 \\
陸域 & 12.3 \\
(熱帯林) & $(3.8)$ \\
\hline & 合 計 \\
\hline
\end{tabular}

るという点において，エコロジカルサービスの経済評価は意義があるといえよう。したがって，エコ ロジカルサービスの経済評価を用いることにより，従来の環境アセスに見る事業者側の一方的な判断 や珍しい動植物がいるという理由付けよりも，より総合的でかつ客観的な評価が可能になる。

以上のように，エコロジカルサービスの経済評価を主張する背景には，生態系の諸機能を明らかに し，それらを財として相対的に評価することにより，環境管理計画や環境アセスメントへ反映させよ うというねらいがあり，批判する前に政策研究や政策決定者とのインタフェースとして試してみる価 值は十分あると考える。

\section{生態系の経済評価に関する研究事例}

さて，生態系に実際值段を付けるとなると，木材資源のように財として比較的容易に現存の価值が算 出可能な場合もあるが, 多くの場合, エコロジカルサービスの経済的な価值は, 土地改变や自然災害 などによる環境負荷量やコストなどから算出される。また，実際に評価しにくい価値，例えば存在価 值などは直接的な評価ができないため仮想評価手法と呼ばれる方法を採用する（今回の特集号の栗山 氏の論文「地域住民にとっての森林の価値」を参照)。熱带林に見られるような多様な樹種が混在し, 地域ごとに利用の仕方が異なる生態系などでは，どれだけの潜在的な経済価値を保持するのか，まし てや森林が存在することによる間接的効果などになると経济評価がなかなか難しいが，これまで森林 のサービス機能について幾つかの直接的，間接的な経済評価が行われてきた(例えば, Panayotou \& Ashton, 1992; Brown \& Pearce, 1994; Myers, 1996 など)。

表 2 はCostanza et al. (1997)が行った地球上のすべての生態系のエコロジカルサービスの経済評価の 要約である。グローバルスケールのエコロジカルサービスを大気成分調節機能(二酸化炭素蓄積・吸 収), 攪乱制御機能 (風水害, 干ばつの防止・軽隇機能), 廃棄物処理機能 (污染物質の除去機能), 塩類循環に関わる機能（窒素固定，窒素，リンなどの循環調節機能）などに分類し, 総額総額33兆 USドルという数值を提示している。生態系別にみた内訳は海洋が 21 兆USドルで全体の $63 \%$ 占め, 陸上生態系のサービス価値は残り $37 \%$ \% 12.3 兆USドルである。ちなみに熱帯林の総額は3.8兆USドル 
で, 陸上生態系価值の約 $30 \%$ を占める。算出された 33 兆ドルという值はあくまで平均值であり, $16-$ 54兆USドルのばらつきがあるとしてしている。また, Costanza et al. (1997) では, この分析結果がど の程度再現性のあるものかという点について，1972年に別の手法 (equilibrium input and output model) を用いて行った調査 (Costanza \& Neil, 1981) と比較している。1972年の調査によれば, 地球全体の生 態系の財としての価格は約9.4兆USドルで, これを Costanza et al. (1997) が調査解析をおこなった1994 年当時の貨幣価值に換算するとおお拈よそ34兆USドルとなり，かなり近似の結果が得られたとしてい る。しかもこれを陸上と海洋に分類するとそれぞれ11.9兆USドル, 22.1兆USドルとなり, 割合からみ ても1994年の調查結果とほほ同様の数值が得られたという。さらに1972年当時のエコロジカルサービ ス機能の総価格はグローバルスケールの G N P の約2.4倍であり, Costanza \& Neil (1981) の調査結果で は同様の比率が1.8倍となっており, 以上のことから彼らの調查結果によるエコロジカルサービスの 総額はリーズナブルな值段となっているのではないかと結論づけている。

しかしながら, サービス機能の主体は森や草地などの生き物や土壤・水といった自然資源であり, 破壊の程度や稀少性，社会環境の変化などの外的要因によって時々刻々と変化する。これらの変化を 捉えるためには，単一時間の単一条件下での算出では不十分である。また, 多くの場合, 土地改変な どの開発行為は地域レベルで行われ, Costanza et al. (1997)のようなグローバルスケールの研究ではな く, それぞれの地域スケールの状況に応じたダイナミックな研究が必要となる。すなわち, それぞれ のサービスや財としての資源に単価を付け, それらの空間的占有面積や密度をもとに総額を出すとい うやり方だけでは, 経済状況などによって変動する地域社会に十分対応できない可能性がある。した がって, 各サービス機能に影響を及ぼす想定される様々な要因（生態的環境要因だけではなく社会環 境なども広く含めた）の割り出しおよび, それら要因間での解析が必要となる。そのためには以下で 述べるエコロジカルサービスのデータベース化が重要な課題になってくると考えられる。

\section{統合環境アセスメントの開発}

エコロジカルサービスのデータベース化

エコロジカルサービスの経済評価を行うためには, エコロジカルサービスの機能の探索するだけでな く, まずサービス機能のカタログ化やデータベース化を行う必要があるが, ここでは経済評価を行う 際の幾つかの検討すべき課題を指摘しておきたい。第一に, サービス機能の経済評価を行う際にはエ コロジカルサービスのデータベースが重要となってくるが, 各機能の要素についての単価表を作成す るだけでは, 一元的なサービス機能の評価にしかなり得ないことから, 各サービス機能を変動させる 要因について明らかにし, 相互の関係について整理した上で十分な解析とモデル化を行っておく必要 がある。例えば, 生物多様性についてみると, 多様性保全機能はもちろんのこと, 物質生産機能, 水 源涵養機能, 炭素吸収蓄積機能など, すべての要素に深く関わっている(表3)。したがって, エコロ ジカルサービスのデータベース化を行うためには表3に示したような取得すべきデータ及び，それぞ れの機能に影響を及ぼすであろう要因などについて整理しておく必要がある。

第二にエコロジカルサービス機能の中には互いに背反する機能か存在するという点である（図1）。 例えば CDM (Clean Development Mechanism) などで, 炭素の吸収機能を重視するのであれば, 出来 るだけ短時間に成長するユーカリやアカシアを植裁樹として選定したほうがメリットが高く短時間に 成果が現れるが, 生物多梯性保全機能は失われてしまう。したがって, すべてのエコロジカルサービ スが同じベクトルをもつ生態系の評価軸にはなり得ないということに注意を払い, どのような条件設 定をすれば複数のサービス機能から得られる価值を最大限活用できるか, すなわち最適解が得られる ような体制を整えておくことが重要である。 
表 3.エコロジカルサービスとそれに及ぼす要因, およびデータベース化のために取得が 必要なデー夕項目

エコロジカルサービス 影響要因 定量化データ

水源涵養森林伐採履歴, 施業管理様式, 地

(水·土壊保全) 形, 生物多様性, 地域社会構造

(人口，インフラなど), 土地利用

土壤浸食量 河川負荷量（植生, 斜面量, 土壤夕イプ, 降水量)

炭素吸収·蓄積森林伐採履歴, 施業管理様式, 地形, 生物多様性, 土地利用, 植生夕イプ

一次生産量, 現存量, 土塞呼吸量, 落 葉落枝供給量, 有機物分解速度

多様性保全 生態系の外形構造, 植生内部の不均 動植物の分布, 生息個体密度, 種類数, 質性，覺乱 (伐採) 履歴，生息地の 連続性 (断片性)

保健文化 生活水準, 経済状態, 社会構造, 自 然との近親度 (関わり合い), 宗教 観, 生物多様性 多様性 (種, 遺伝), 食物連鎖, 種間相 互作用

仮想評価手法による定量的価値（CVM， Conjointなどによる選択価值, 存在価值)

第三の課題として, 森林伐採や搬出手法の改善に代用されるような技術革新や制度の改革や導入に よって図 1 で示した最適解のアップグレードが可能になるということを指摘しておきたい。例えば, 前述のように，ある意味において生物多様性保全機能と木材生産機能は互いに相反するが，森林認証 制度（例えば，FSC や ISO14001）の導入などにより，施業方法や伐採時および伐採後の管理方法が 改善されると, 従来の森林管理方式に比べ高い利潤が得られる可能性がある。あるいは短期的に見れ ば㛜しい管理基準のためにコストが高くつかもしれないが，長期的に見れば環境への負荷が軽減され る分だけ，そのコストの回収が可能になることも考えられる。今後は，エコロジカルサービスの機能 の整理と最適解を得るための管理基準を考慮する必要があり, 各要因間の解析を可能にするデータベ ースの構築が重要な役割を果たすと考える。

\section{エコロジカルサービスのGIS化による環境基本台帳}

次にエコロジカルサービスの経済評価を実際の環境管理プランへどのように応用するかという点につ いて，以下我々がマレーシア半島部のパソ保護林およびその周辺域（図 2 ) で行っている研究事例を 紹介しながら，述べることにする。パソ保護林の研究プロジェクトの歴史については古くは1970年代 前後に開始されたIBP（国際性物事業計画）やマレーシア大学（University of Malaya）とスコットラン ドのアバディーン大学（University of Aberdeen）との共同研究に端を発し，近年では日本の国立環境 研究所や森林総合研究所, マレーシアのマレーシア森林研究所, マレーシアプトラ大学 (University Putra Malaysia）との共同研究，スミソニアン熱帯研究所が中心となる熱帯長期観測モ二タリングプロ ジェクトなど数多く研究プロジェクトが展開中である。これらの概要などについては本稿では詳しく 述べないので, Lee et al. (1995) やAshton \& Okuda (in press) などを参考にされたい。

パソ保護林およびその周辺域においては約30年にわたる生態学的研究成果や資料が蓄積されてお り，我々はまず，これらの情報をもとに天然林や二次林をはじめとする種々の生態系のサービス機能 について，パソ保護林を中心に約 $60 \mathrm{~km} \times 60 \mathrm{~km}$ の地域をパイロットエリアとして抽出し，この地域内 のエコロジカルサービスのデータベース化及びそれらをGIS情報として統合化する試みを行ってい 
図 1.エコロジカルサービスのトレードオフ関 係。サービス1と2から得られる価值の合計は点A が載る実線上で最大となるが, 制度の改善・導入 (森林認証制度の導人や管理基準の見直し), 技術 革新（森林伐採に際しての施業方法の改良など）, 研究開発 (エコロジカルサービスの情報集積など) などにより，最適解をアップグレードすることが 可能である(点 Bが載る波線上の曲線)。 Millennium Ecosystem Assessment Committee (1998): Millennium ecosystem assessment: strengthening capacity to manage ecosystems for human development. http:/www.ma-secretariat.orgより (一部改変)。

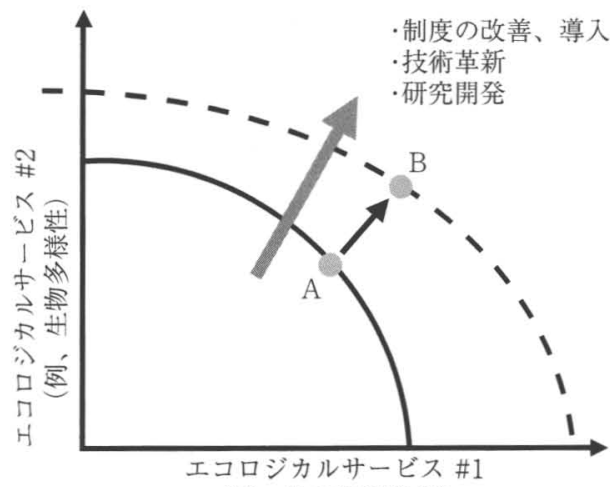

(例、炭素吸収機能)

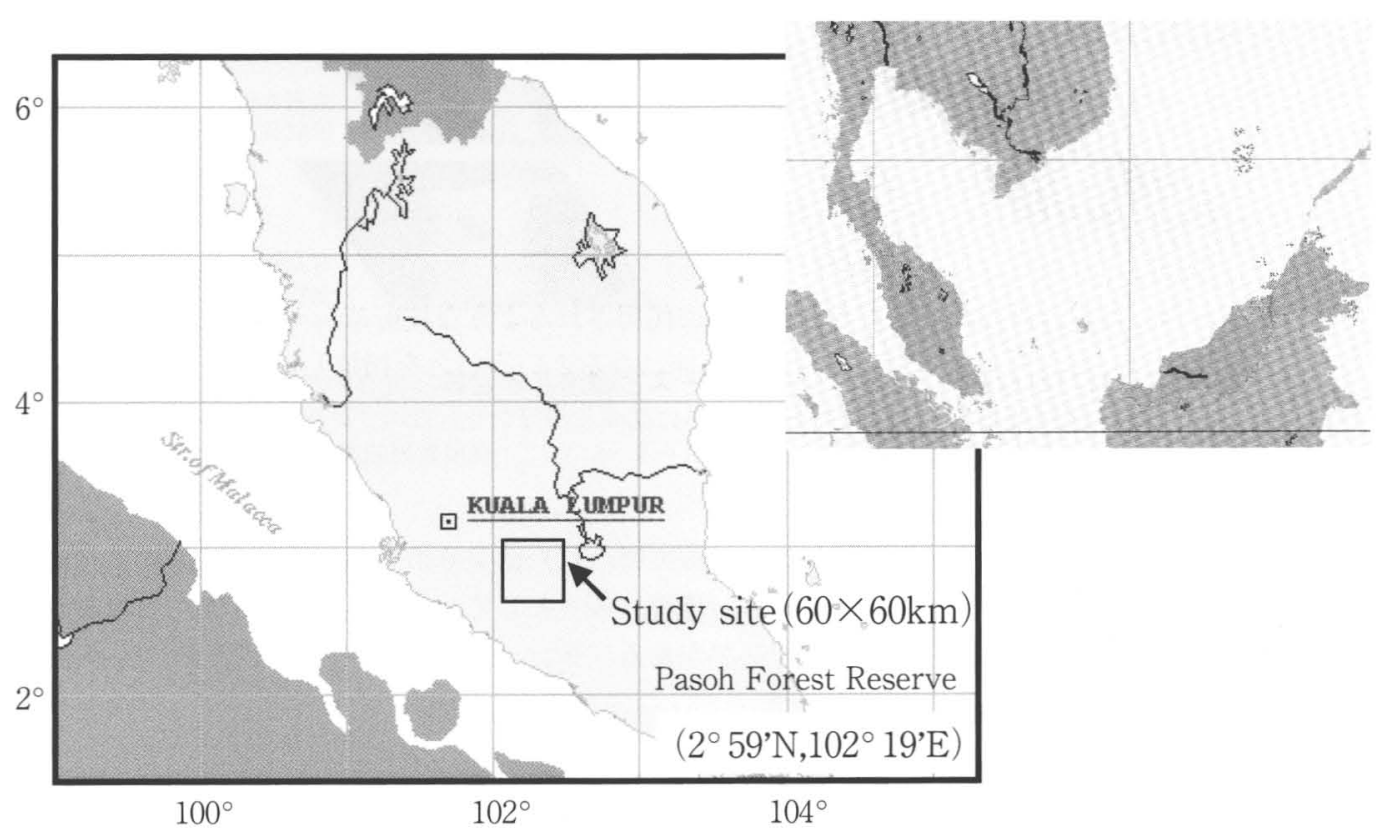

図 2.パソ保護林と統合化環境アセスメントのモデルサイトとして設定した調査地 (図中の枠で囲まれた地域 $(60 \mathrm{~km} \times 60 \mathrm{~km}$ )。

る。具体的には既存の植生図，土壤図，地形図などをもとにそれらをGIS化すると同時に，これに各 生態系のサービス機能，経済的な価值などに関するデー夕を加えたうえで，エコロジカルサービスを マップ化し，これらを全部統合化した環境基本台帳をつくるという試みである（図３）。このような 環境基本台帳を策定することにより，特定エリアの開発を行う場合に，まず，現存量や生物多様性な どの現状はどうなのか，それに対してどういう開発や事後の管理形態をとったときにどんなりスクが あるのか，といった想定できる内容を定性的に，また定量的に示す，あるいは予測することが出来る (図 4)。また，その結論に至ったプロセスも参照でき，元のデータに立ち返ることも可能である。さ らに，導き出した結論に対して，土地改変などに伴うリスク，環境への影響を照らし合わせながら， ミティゲーションプランの導入など，フィードバックをかけることが可能になると考える。ただし， 

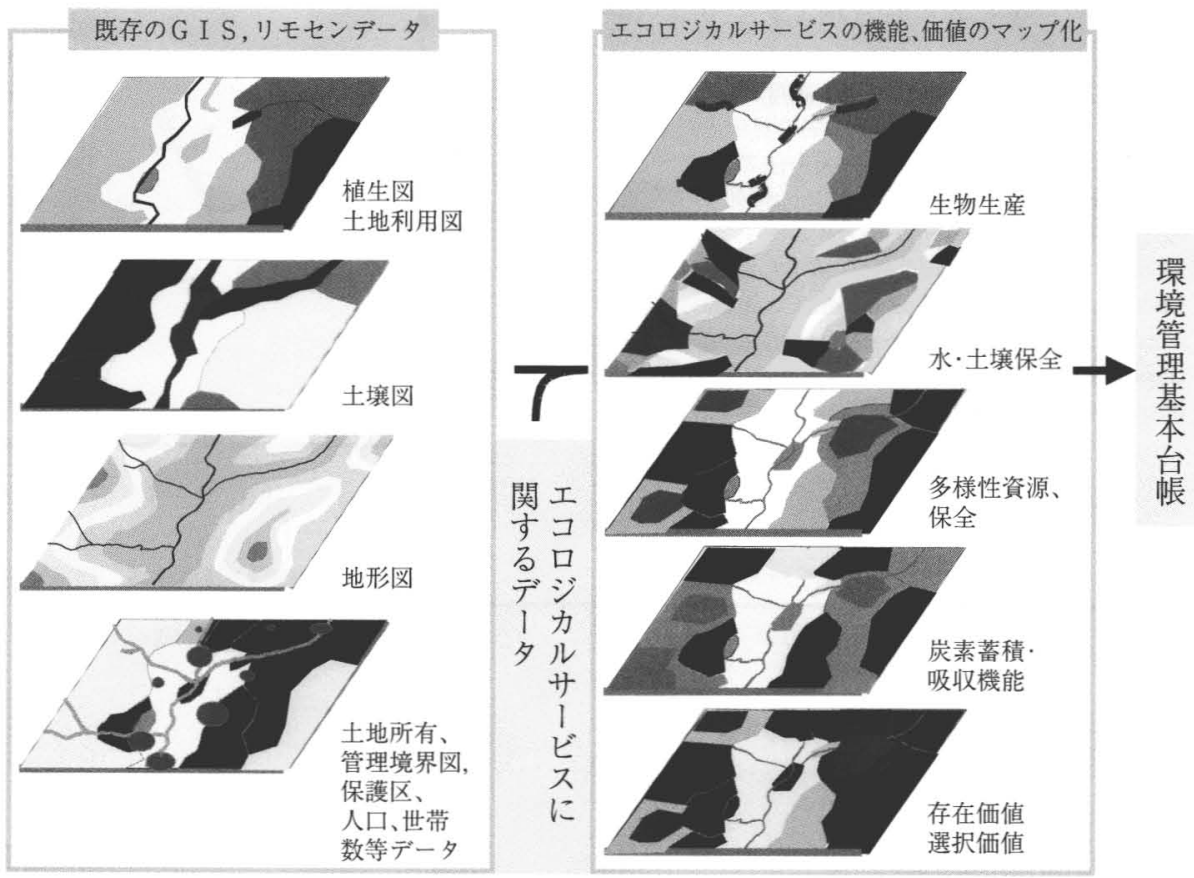

図 3.エコロジカルサービスのデータベースと環境基本台帳。既存の資料を基にした GISと各生態系のエコロジカルサービスに関する情報をもとにエコロジカルサービス の二次元マッピングを行う。さらにそれらを元にして，環境管理基本台帳を作成する。

これらの場合, 重要なのはシミュレーションによって得られた結果そのものではなく, どのようにし て結果が導き出されたかというプロセスであり，環境リスクとしてどういった要因がキーとなるかを 割り出すという点であることに留意しておく必要がある。また，用いたデー夕の限界性についても明 確にしておくことも必要である。

\section{エコロジカルサービスと統合環境アセスメント}

エコロジカルサービスのマッピングデータをもとに, 環境基本台帳のような開発に際した環境アセス メントの支援ツールから, もう一歩進めて, 最適土地利用計画 (土地適正評価フレーム) やゾーニン グプランも提示するといった統合環境アセスメントを行うことも可能である。これは，開発の計画が 持ち上がってからアセスメントを行うのではなく, 多くのデー夕を基にあらかじめ開発を行う場所や 開発監視地区を選定することである。例えば土壇浸食防止という機能からいうと，この地区はプラン テーションではなく, 少なくとも生産林で保っておく必要があるとか, 樹木の遺伝的な交流が正常に 行われるためには少なくとも一定距離の範囲内に別の森林パッチが必要になるので，その林分は生产 林ではなく自然林として保持しておかなければならないとといった提案や，野生生物の生息域や正常 な繁殖を確保する場合も，林分パッチ間の距離，生物の生息密度，多様性の状況，人口・集落密度な どの情報をもとに，緑の回廊設置を設定する候補地や開発監視地区をあらかじめ選定しておくことな どが可能になる。

前述したパイロットエリアでは最近20-30年の東南アジア地域の森林減少の典型的なパターンがみ られた。パイロットエリアに㧍けコ土地利用変化について, Landsa衛星画像, 及び現地で発行して 
エコロジカルサービスの現状分析

-木材、生物資源量

- 炭素蓄積量、機能

- 土壤保全機能

- 野生生物、多様性の保全機能

-伐採などの攪乱履歴

・社会経済的な背景

土地利用改変のオプション

-土地利用形態の改変

・森林を維持したままでの管理

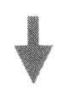

コスト・ベネフィット分析

・リスクアセスメント

- 社会·経済的影響分析
代替案の提案

ミティゲーションプラン

の提示

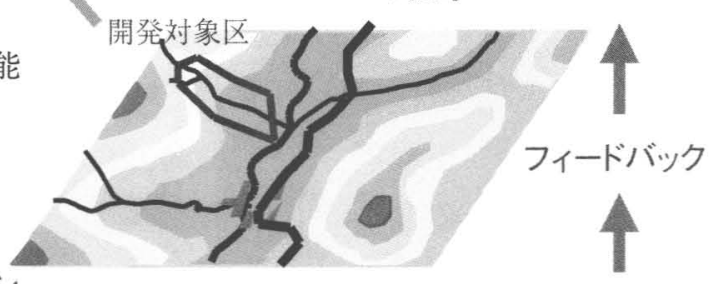

エコロジカルサービス機 能と価值のシナリオ分析

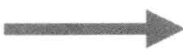

図 4.エコロジカルサービスの価值や機能評価によるリスクアセスメントの開発。

いる地形図から土地利用変化を解析したことろ，1970年前半から1990年後半にかけて森林面積は2362 $\mathrm{km}^{2}$ (全域の65.6\%) から $1057 \mathrm{~km}^{2}(29.4 \%)$ に激減し, 逆にアブラヤシのプランテーションは, $176 \mathrm{~km}^{2}$ から741 km²ほぼ 4 倍強に増加していることがわかった (Okuda et al., in press)。この間の森林の年平 均減少率は約 $2.2 \%$ ，東南アジア地域の森林面積の減少率 $(1.2-1.5 \%, \mathrm{FAO}, 1993)$ と比較しても高 い值である。現在プランテーション開発は小康状態であるが，この地域の北西部はクアラルンプール 郊外に隣接しているため, 近い将来都市化や宅地開発も計画されており, 今後も森林減少や森林の質 的劣化，および植生の断片化が起こる可能性が高い。

エコロジカルサービスを用いた統合環境アセスメントの一例として，パソ保護林周辺のパイロット サイトを対象地として, 森林を伐採してプランテーションに改変する際に, 森林の土壤保全機能など のエコロジカルサービスがどのように変わっていくのか, すなわち, どの程度の環境リスクがあるの か, さらに, これに森林のもつ炭素蓄積機能を加味した場合はどのくらいのコストを支払う必要があ るのかなどについて解析を試みたのでその一部を以下に紹介する。

パイロットエリアの植生情報, 地形情報, 土塞情報, 土地利用情報などをもとに200 mメッシュ毎 に The Universal Soil Loss Equation (USLE, Wischmeier \& Smith, 1978) を適用し，パイロットエリアのす ベてをプランテーション（オイルパーム）に変換したとした際の平均土畩浸食量（ton/ha/yr）を算出 した（図５）。図中のネットで覆われた部分は林班区（コンパートメント）を示し，ほぼ熱帯林が残 存する地域に相当する。灰色で色分けした箇所が, 年間 10 ton/ha以上の土㥽浸食量がある箇所である。 土䁃浸食量の限界值が10 ton/ha/yrであるとすれば（Schertz, 1983), 灰色のエリアは森林として温存す る, ないしは復元すべき地域であり，一方，白色の地域はオイルパームプランテーションへ転換する ことができる地域を示す。

さらに進めて, 森林を伐採し, プランテーションへ土地利用転換する際のコスト, エコロジカルサ 一ビスの経済的な価值の損失, プランテーションから得られる利益を勘案して費用便益分析 (Cost \& Benefit Analysis）をGISを用いて行った（図 6)。ここでは, エコロジカルサービスとして, 物質生産 

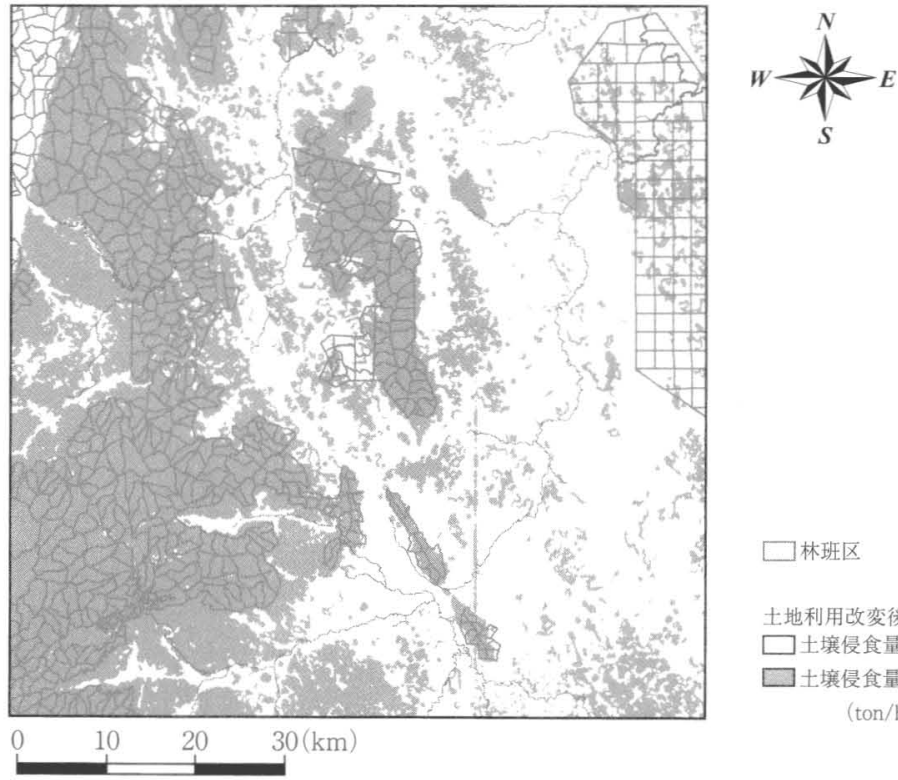

$\square$ 林班区

土地利用改変後,

$\square$ 土裹侵食量 $<10$

$\square$ 土墡侵食量 $>10$

(ton/ha/yr)

図 5.土地利用をアブラヤシプランテーションと仮定した場合のパイロットサイトにおける土壤浸食 量 (USLE) の分布。網掛け部分は林班区を示す。灰色部分は土壤浸食量が 10 ton/ha/yr 以上，白色部分は 10 ton/ha/yr以下の地区を示す。

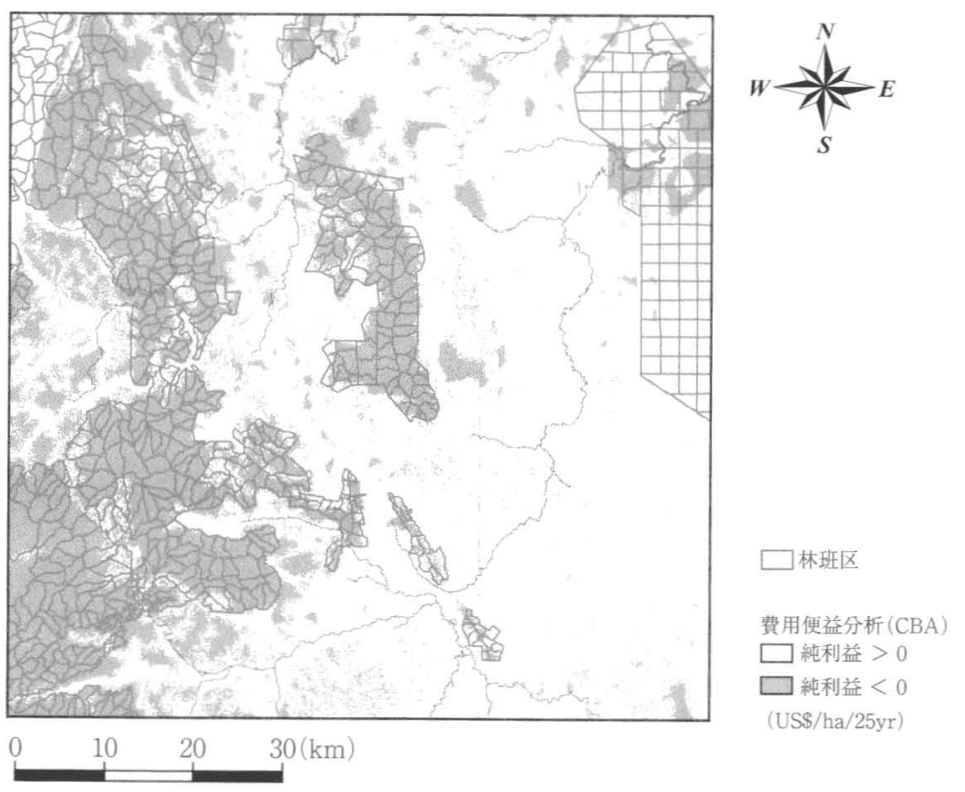

図 6.パイロットサイトにおける費用便益分析（Cost \& Benefit Analysis）。エリア全体をアプラヤシのプ ランテーションに転換するとして, そこから得られる収益, コスト（生産物の運搬費用，農道建設十エコ ロジカルサービス（土㙵保全機能, 炭素蓄積機能による価值）を算出し，利益がでる地域（白色）と損益 がでる地域 (灰色) とに区分した（吉田ほか，未発表資料)。 
機能 (木材生産), 土䁃保全機能 (土壌浸食量), 炭素蓄積機能を対象に解析を行った。またプランテ ーション建設および運営に際しての直接的なコスト，例えば農道建設費用，収穫物の運搬費用，木材 資源の償却などを加味した。森林として残すべき，あるいは復元すべき地域は林班区とおおよそ重な るが，林班区以外の一部地域では土畩浸食などによる環境負荷がかさむためにプランテーションとし て開発しても利潤が出ない地域ある。土壤浸食のみからみた場合（図5）と比べ森林として残す心゙き 部分が若干減少したが，オイルパームの生産という利益分を考慮に入れることで，より現実に近い土 地利用形態を提示していると考えられる。

以上に示したものは，GISを用いたシミュレーションモデルであり，ある一時期のエコロジカルサ ービスや財の経済的な価值のみを対象とした算出結果である。今後は時系列的なデー夕および生物多 様性などを考慮に入れた解析や各サービス機能の経済評価に影響を与える要因を抽出して，統合環境 アセスメントの完成度を高めていくことが重要である。

\section{おわりに}

本稿ではエコロジカルサービスの探索とデータベース化，及びエコロジカルサービスのGIS化による 環境管理プログラム策定の重要性について指摘した。データベース構築にあたっては表 1 や表3で示 した機能以外のあらたな機能探索も重要であるが, 炭素蓄積機能などのように機能そのものは十分理 解できていても, 地域スケールで詳細に算出する際に, デー夕の欠測や算出根拠のためのモデル式の 不備などの問題が生じる場合もある。実際に，パソ保護林関連のプロジェクトを進めるうちに，これ まで多くの情報が蓄積していると思われた炭素循環については, 数多くのデータの空白域や欠測があ ることや，林分の立地条件による現存量などの不均質性などの問題があることが判明した。こうした データの欠如や信頼性に関わる部分についてはサービス機能のデータベース化と同時並行的に, リス ク管理プログラムやゾーニングプログラムの積算根拠となるデータを絶えず補正していく必要があ る。また，このような柔軟性をもたせなければ，単なる算出結果だけが政策決定者の間で一人歩きし てしまう危険性が十分にあり得る。さらに，こうした管理プログラムは用いたデータソースの検索や revision が絶えずおこなえ，どのような根拠に基づいて結論に至ったかを示せるシステムにしておく ことが肝要である。そうすることにより，一定の基準に基づいたエコロジカルサービスの経済的な価 值を評価することに意義が見いだされると考える。

\section{引用文献}

Adger, W. N., Brown, K., Cervigni, R. \& Moran, D. 1995. Total economic value of forests in Mexico. Ambio 24: 286-296.

Ashton, P. S. \& Okuda T. History in ecological studies in Pasoh Forest Reserve. In: Okuda, T., Niiyama, K., Thomas, S. C., Manokaran, N. \& Ashton, P. S. (eds.), Ecology and Natural History of a Southeast Asian Tropical Rainforest. Springer (in press).

Brown, K. \& Pearce, D.W. (eds.), 1994. The Causes of Tropical Deforestation: The Economic and Statistical Analysis of Factors Giving Rise to the Loss of the Tropical Forest. London: University College London Press, $338 \mathrm{pp}$.

Costanza, R., d'Rage, R., de Grout, R., Farber, S., Grass, M., Hannon, B., Limburger, K., Name, S., O'Neill, R.V., Paulo, J., Ruskin, R.G., Sutton, P. \& van den Belt, M. 1997. The value of the world's ecosystem services and natural capital. Nature 387: 253-260. 
$\&$ Neil, C. 1981. The energy embodied in the products of the biosphere. In: Mitsch, W. J., Bosserman, R. W. \& Klopatek, J. M. (eds.), Energy and Ecological Modeling, 745-755. Elsevier, New York.

Daily, G. C., Alexander, S., Ehrlich, P. R., Goulder, L., Lubchenco, J., Matson, P. A., Mooney, H. A., Postel, S., Schneider, S. H., Tilman, D. \& Woodwell, G. M. 1997. Ecosystem services: benefits supplied to human societies by natural ecosystems. Issue in Ecology No. 2: 1-16.

FAO 1993. Forest Resource Assessment 1990: Tropical Countries. U.N. Food and Agric. Org., Rome.

Kumari, K. 1996. Sustainable forest management: myth or reality? Exploring the prospects for Malaysia. Ambio 25: 459-467.

Lee, S. S., Chan, H. T., Kirton, L. G., Lim, B. L., Ratnam, L., Saw, L. G. \& Francis, C. 1995. A Guide Book to Pasoh. FRIM Technical Information Handbook, No 3. Kepong, Malaysia, 73 pp.

Myers, N. 1996. The world's forest: problems and potentials. Environmental Conservation 23: 156-168.

Okuda, T., Suzuki, M., Adachi, N., Yoshida, K., Niiyama, K., Nur Supardi, M. N., Manokaran, N. \& Mazlan, H. Logging History and Its Impact on Forest Structure and Species Composition in the Pasoh Forest Reserve Implication for the Sustainable Management of Natural Resources and Landscapes-. In: Okuda, T., Niiyama K., Thomas, S. C., Manokaran, N. \& \& Ashton, P. S. (eds.), Ecology and Natural History of a Southeast Asian Tropical Rainforest. Springer, (in press).

Panayotou, T. \& Ashton, P. 1992. Not by Timber Alone - Economics and Ecology for Sustaining Tropical Forests. Washington D.C: Island Press, 282 pp.

Schertz, D. L. 1983. The basis for soil loss tolerance. J. of Soil and Water Conservation 38: 10-14.

Wischmeier, W. H. \& Smith, D. D. 1978. Predicting Rainfall Erosion Losses - A Guide to Conservation Planning. Agriculture Handbook No. 537. Washington, D.C: US Department of Agriculture.

山縣光晶, 小原正人, 内田敏博, 片桐達夫, 寺田辰好, 上田浩史, 藤江達之（編） 1989. 森林 ·林

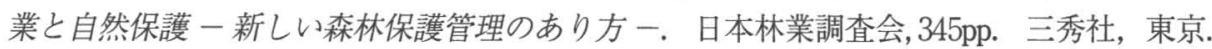

奥田敏統, 吉田圭一郎, 足立直樹＼cjkstart熱帯林のエコロジカルサービスを探る 一生態研究の接点と統合環境管理プロジェクトヘ向けてー

熱帯域生態系の資源の持続的利用と生物多様性などの保全を推進するための第一歩として統合環境ア セスメントを提唱した。このアセスメントでは, まず対象地の様々な生態系のエコロジカルサービス に関するデータ収集と, サービスや財に関するデータベースの構築を重要な柱とする。サービス機能 の中には互いに相容れない機能もあるため, これらの背景にある要因間を整理した上で, 様々なサー ビス機能によって得られる価值が最大限に引き出せるような管理方式を提唱する必要がある。さらに エコロジカルサービスのデータベースを利用し, リスクアセスメント, 最適土地利用計画などへ発展 性についても検討も重要な課題である。本稿は昨年（2001年6月）に東京都立大において開催した熱 帯生態学会公開シンポジウム「熱帯林のエコロジカルサービスを探る」における講演「エコロジカル サービスとは」をもとに, 熱帯林のエコロジカルサービスについての紹介や今後の課題について述べ たものである。本シンポジウムでは炭素蓄積・吸収機能, 水源涵養機能, 多様性保全機能などについ て, 生態学的, 経済学的な立場からの専門の研究者の方々にご講演をお願いした。 


\section{正 誤 表}

TROPICS Vol. 11(4)内に掲載されている「熱帯林のエコロジカルサービスを 探るー生態研究の接点と統合環境管理プロジェクトへ向けてー」(pp. 193-204) の表 2 に間違いがありました。正しくは以下の通りとなります。

表 2.グローバルスケールで見た全エコロジカルサービスの経済的価值 (Costanza et al., 1997 より抜粋)

\begin{tabular}{lc}
\hline エコロジカルサービス & 価値 (兆US \\
機能別 & \\
大気成分調節 & 1.3 \\
攪乱調節（風水害など） & 1.8 \\
廃棄物処理（污染物質浄化など） & 2.3 \\
塩類循環（炭素, 窒素循環など） & 17.1 \\
その他 & 10.8 \\
生態系別 & \\
海洋 & 21.0 \\
陸域 & 12.3 \\
(熱带林) & $(3.8)$ \\
\hline & 合 計 \\
\hline
\end{tabular}

